\title{
PEMODELAN DINAMIKA ARUS PERAIRAN INDONESIA YANG DISEBABKAN OLEH ANGIN
}

\section{CURRENT DYNAMICS MODELLING OF INDONESIAN WATERS WITH WIND AS THE INDEPENDENT VARIABLE}

\author{
Ika Kusumawati \\ Program Studi Perikanan, Fakultas Perikanan dan Ilmu Kelautan, \\ Universitas Teuku Umar, Aceh Barat \\ Korespondensi: ikakusumawati@utu.ac.id
}

\begin{abstract}
Research on current dynamics modelling in Indonesian waters with wind employed as independent variable has been observed. The purpose of this study was to model the hydrodynamic equations due to the influence of the wind in Indonesia waters in the form of visualization described consisting of wind circulation pattern and pattern of current movement in the west and east monsoon season. To analyze the data obtained during the study, researchers used a descriptive approach. The results showed that the west wind season (December, January, and February) blow from the northeast to the southwest then turning southeast. Whereas the east wind season (June, July, and August) blows from the southeast to the northwest and then turn to the northeast. On the surface layer shows the current movement in general follows the movement of the wind direction in which the current speed is very dominant occurred in some waters, such as the Karimata Strait, the Java Sea, the South China Sea, and the Arafuru Sea. The dominant current velocity in the layer of 100-200 $\mathrm{m}$ in the water of eastern equator and the South China Sea in the west season has recorded a current speed reaches $20 \mathrm{~cm} /$ s. while in the east monsoon which occurs in the equatorial waters of the eastern part, in the Maluku Sea, the Seram Sea and nearby the Arafuru Sea current velocity reaches $40 \mathrm{~cm} / \mathrm{s}$.
\end{abstract}

Keywords: Current Dynamics, Modelling of Indonesian Waters, Wind

\section{Pendahuluan}

Indonesia secara geografis terletak di antara dua benua, Asia dan Australia, dan dua samudera, Samudera Hindia dan Samudera Pasifik (Stewart, 2002). Hal ini menyebabkan perairan Indonesia mempunyai tinggi permukaan air yang berbeda, sehingga arus laut dari Samudera Pasifik mengalir ke Samudera Hindia dengan debit air yang sangat besar, lebih dari $15.000 .000 \mathrm{~m}^{3} / \mathrm{s}$ (Djamil, 2006).

Pertukaran air dari dua samudera tersebut dengan kombinasi rupa bumi dasar laut yang bervariasi topografinya juga mengakibatkan banyak terdapat lokasi upwelling di mana naiknya massa air dari lapisan bawah ke lapisan permukaan. Massa air yang naik ini mempunyai suhu yang dingin, salinitas yang rendah dan membawa zat-zat hara seperti fosfat dan nitrat yang sangat diperlukan oleh plankton. Daerah upwelling merupakan daerah yang memiliki potensi perikanan laut sangat besar ( Mann and lazer, 1991). 
Angin merupakan salah satu unsur iklim yang mempunyai peranan penting dalam interaksi antara laut dan atmsofer sehingga mendapat perhatian tidak hanya dalam penelitian meteorologi saja tetapi juga dalam penelitian kelautan. Bagi dinamika perairan laut terutama di lapisan permukaan angin merupakan sumber energi utama. Transfer energi dari angin permukaan ke laut akan menyebabkan terjadinya gelombang laut dan arus permukaan laut (Wyrtki, 1961; Nontji, 2005; Arief, 1994; Dahuri et al, 1996).

Informasai tentang pola arus dan angin dari lapangan tidak mungkin diperoleh secara lengkap. Simulasi dinamika oseanografi dapat memprediksi kuantitas fisik di tempat yang diinginkan, dengan menggunakan persamaan differensial parsial yang dikenal dengan "Navier Stokes". Persamaan differensial untuk dinamika oseanografi diperoleh dengan memperhatikan beberapa fenomena fisika seperti hukum kekekalan massa, hukum Newton, gaya gravitasi, gaya Coriolis, gesekan angin, dan tekanan atmosfer (Pond and Pickard, 1983).

Dengan demikian penelilitian ini merupakan salah satu cara yang sangat efisien dalam menjaga dan eksplorasi sumber daya laut yang ada di dalamnya, sehingga gerakan massa air yang dilalui di perairan Indonesia dapat diketahui. Penelitian ini bertujuan menentukan pergerakan arus dan sirkulasi angin pada musim barat dan musim timur.

\section{Metode Penelitian}

Penelitian ini dilakasanakan pada Agustus 2007 - Februari 2008. Pengolahan data dilakukan dilakukan Laboratorium Ilmu Kelautan. Dalam melaksanakan penelitian ini digunakan seperangkat komputer sebagai alat bantu untuk menyelesaikan persamaan secara numerik dan pembuatan visualisasi hidrodinamika laut. Perangkat lunak (software) yang digunakan adalah bahasa program fortran 77 dan GMT under linux. Metode yang digunakan dalam penelitian ini adalah analisis deskriptif yaitu memberi gambaran umum tentang pola umum sirkulasi angin permukaan berdasarkan hasil pengolahan data.

Penelitian akan dilakukan dengan tahapan sebagai berikut:

1. Menentukan dan memasukkan data syarat batas pasang surut yang terdiri dari Amplitudo dan fase dengan resolusi $1^{\circ}$ (Zahel et al, 2000) diinterpolasi menjadi resolusi 10'.

2. Memodelkan hidrodinamika untuk mendapatkan $\mathrm{u}, \mathrm{v}, \mathrm{w}$ dan $\zeta$.

Domain model wilayah meliputi $94^{\circ} 30^{\prime} \mathrm{BT}-145^{\circ} 30^{\prime} \mathrm{BT}$ dan $15^{\circ} 30^{\prime} \mathrm{LU}-14^{\circ} 30^{\prime}$ LS. Dalam penelitian ini, model didiskritisasi 10' dalam arah x dan y. Dalam arah vertikal, model terbagi menjadi 11 lapisan berdasarkan data Levitus, 0-10 m, 10-20 m, 20-30 m, 30-50 m, 50-100 m, 100-200 m, 200-500 m, 500-1000 m, 1000-2000 $\mathrm{m}, 2000-5000 \mathrm{~m}, 5000-12000 \mathrm{~m}$. Langkah waktu diatur pada $\mathrm{t}=600 \mathrm{dt}$ (Zahel et a1., 2000).

3. Memodelkan arus akibat angin bulanan (Rizal, 2004). 


\section{Persamaan Dasar Hidrodinamika Laut}

Gaya-gaya utama yang mempengaruhi dinamika oseanografi (Pond and Pickard, 1983) terdiri atas:

1. Gravitasi, yang mencakup gaya oleh matahari, bulan, dan planet lainya. Percepatan gravitasi yang digunakan adalah $\mathbf{g}=\mathbf{g}_{\text {bumi }}+\boldsymbol{\Omega} \times(\boldsymbol{\Omega} \times \mathbf{R})=9,8 \mathrm{~m} / \mathrm{dt}^{2}$.

2. Gesekan angin, untuk arah tangensial berupa gesekan dan arah normal berupa tekanan.

3. Tekanan atmosfer (dari udara) dan tekanan air laut termasuk perbedaan densitas akibat perbedaan salinitas dan temperatur.

$\mathbf{F}_{\text {tekanan }}=-\boldsymbol{\alpha} \nabla \mathbf{p}$

4. Seismic yang berasal dari kegiatan tektonik di dasar laut.

5. Gaya Coriolis terjadi ketika benda bergerak lurus diamati oleh objek yang bergerak rotasi (pengamat diam dibumi). Atau gaya palsu pada bidang yang bergerak ketika gerakannya diobservasi terhadap bumi yang berputar. Di mana bagian bumi utara bergerak ke kanan dan bagian bumi selatan bergerak kearah kiri. Perbedaan gerakan ini disebabkan karena adanya perbedaan antara gerakan kutub dan gerakan equator. $\mathbf{F}_{\text {coriolis }}=-\mathbf{2} \Omega \times \mathbf{V}$

6. Gaya gesek baik yang terjadi antara air dan dasar laut maupun air laut dengan air laut (turbulensi). Besarnya gaya gesek akibat turbulensi tersebut sebanding dengan konstanta konstanta turbulensi $A$.

$\mathbf{F}_{\text {turbulensi }}=\mathbf{A} \nabla^{2} \cdot \mathbf{V}$

Definisi gaya yang digunakan untuk dinamika oseanografi ialah gaya persatuan massa. Sehingga dimensi gaya yang digunakan berdimensi percepatan

$\mathrm{LT}^{-2}$. Oleh karena itu definisi gaya persatuan massa adalah

$$
\mathbf{F}=\mathrm{a}=\frac{d V}{d t}
$$

Persamaan air laut yang menggunakan gaya persatuan massa dinamakan persamaan kecepatan.

Karena $\mathbf{V}$ merupakan fungsi posisi dan waktu $\mathbf{V}=\mathbf{V}(\mathrm{x}, \mathrm{y}, \mathrm{z}, \mathrm{t})$, maka

$$
\begin{aligned}
\mathrm{F} & =\frac{d V}{d t}=\frac{\partial V}{\partial t}+\frac{\partial V}{\partial x} \frac{d x}{d t}+\frac{\partial V}{\partial y} \frac{d y}{d t}+\frac{\partial V}{\partial z} \frac{d z}{d t} \\
& =\frac{\partial V}{\partial t}+\mathrm{u} \frac{\partial V}{\partial x}+\mathrm{v} \frac{\partial V}{\partial y}+\mathrm{w} \frac{\partial V}{\partial z}
\end{aligned}
$$

\section{laju perubahan lokal suku konvektif}

Ruas kanan persamaan (5) terdapat suku lokal berupa $\frac{\partial V}{\partial t}$ dan suku yang berubah terhadap posisi yang dinamakan suku konvektif.

Bila seluruh gaya dijumlahkan diperoleh persamaan dasar dinamika oseanografi (Pond and Pickard, 1983).

$\mathbf{F}=\mathbf{F}_{\text {tekanan }}+\mathbf{F}_{\text {coriolis }}+\mathbf{F}_{\text {grafitasi }}+\mathbf{F}_{\text {gesekan }}+\mathbf{F}_{\text {lainnya }}$ 


$$
\mathbf{F}=\frac{d V}{d t}=-\boldsymbol{\alpha} \nabla \mathbf{p}-\mathbf{2} \mathbf{\Omega} \times \mathbf{V}+\mathbf{g}+\mathbf{A} \nabla^{2} \cdot \mathbf{V}+\mathbf{F}_{\text {lainnya }}
$$

\section{Hasil dan Pembahasan}

\subsection{Arus}

Menurut letaknya arus dibedakan menjadi arus permukaan, arus pada kedalaman tertentu, dan arus bawah. Arus permukaan adalah arus yang bergerak di permukaan laut, di mana arah arus permukaan memiliki hubungan yang erat dengan angin. Sedangkan arus bawah adalah arus yang bergerak di bawah permukaan laut yang sangat berkaitan dengan gesekan dasar. Aliran arus yang terjadi pada setiap lapisan akan berbeda-beda. Berikut ini beberapa pola arus pada lapisan yang berbeda, yaitu arus permukaan, arus pada lapisan 100-200 m, dan arus pada lapisan dasar. Arus dari masing-masing lapisan akan di gambarkan berdasarkan musim, musim barat diwakili oleh bulan Februari dan musim timur diwakili oleh bulan Agustus (Rizal, 2004).

\subsubsection{Arus Permukaan pada Musim Barat dan Musim Timur}

Gambar 1 pada musim barat menunjukkan bahwa arus dari Samudera Pasifik mengalir ke arah barat laut di bagian utara khatulistiwa menuju ke Laut Mindanoa, Laut Sulawesi, Laut Sulu, dan Laut Cina Selatan. Pada daerah khatulistiwa, arus dari Samudera Pasifik masuk ke Laut Halmahera, Laut Maluku, Selat Makasar, dan Selat Karimata. Hal ini sejalan dengan gambaran Wyrtki (1961) menguatnya arus khatulistiwa utara dan melemahnya arus khatulistiwa selatan.

Di Selat Karimata arus masuk melalui Laut Cina Selatan dengan kecepatan 100$120 \mathrm{~cm} / \mathrm{s}$. Arus dari Selat Karimata menuju ke Selat Malaka, Selat Sunda, dan Laut Jawa. Arus di Selat Sunda menuju ke Samudera Hindia. Di Laut Jawa arus dengan kecepatan $100 \mathrm{~cm} / \mathrm{s}$ mengalir ke Laut Flores dan Laut Banda. Di Laut Banda arus dari Selat Makasar, Laut Maluku, dan Laut Halmahera bergabung mengalir ke arah tenggara melalui Laut Arafuru dengan kecepatan $100 \mathrm{~cm} / \mathrm{s}$. Arus Laut Timor yang merupakan masukan dari Samudera Hindia juga menuju ke arah tenggara dengan kecepatan arus $60-80 \mathrm{~cm} / \mathrm{s}$. Arus yang mengalir pada musim barat mengikuti arah angin yang bertiup dari timur laut ke arah barat daya kemudian berbelok ke arah tenggara.

Arus permukaan pada bagian selatan khatulistiwa mengalir dari tenggara dan timur diperlihatkan pada Gambar 1. arus dari tenggara menuju ke Samudera Hindia melewati Laut Arafuru dan Laut Timor. Sedangkan arus dari timur mengalir ke Laut Arafuru dengan kecepatan $80 \mathrm{~cm} / \mathrm{s}$ menuju ke Laut Banda. Dari laut Banda arus berpencar mengalir ke Laut Jawa, Selat Makasar, Laut Maluku, dan Laut Halmahera. Di Laut Jawa arus dengan kecepatan 100-120 cm/s keluar menuju Samudera Hindia melalui Selat Sunda. Kecepatan arus di Selat Karimata mencapai $140 \mathrm{~cm} / \mathrm{s}$, arus ini merupakan arus masukan dari Laut Jawa. Dari Selat Karimata arus keluar munuju Selat Malaka dan Laut Cina Selatan.

Di bagian utara khatulistiwa arus dari Laut Cina Selatan, Selat Makasar, Laut Maluku, dan Laut Halmahera mengalir ke arah timur yaitu Samudera Pasifik. Pada Samudera Pasifik arus ini menuju ke arah timur laut dan tenggara. Arah arus pada bulan 
ini dapat dikatakan bergerak berlawanan dengan arah angin yang bertiup dominan ke timur laut. Hal ini dapat diakibatkan oleh mulai menguatnya arus khatulistiwa selatan dan melemahnya arus khatulistiwa utara (Wyrtki, 1961) yang memungkinkan menguatnya Mindanao Eddy.
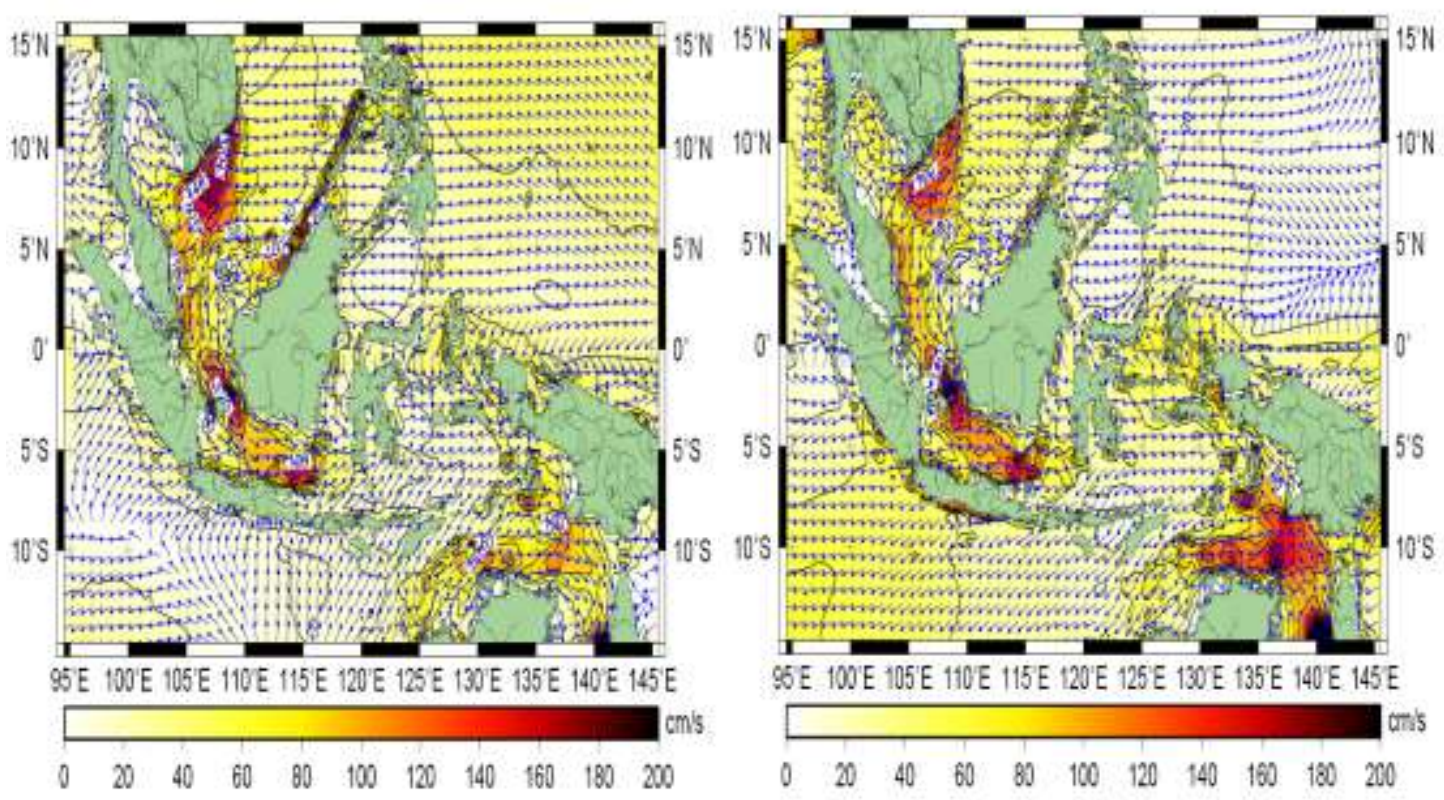

Gambar 1. Pola arus permukaan pada bulan Februari (Musim Barat) Agustus (Musim Timur).

\subsubsection{Arus Lapisan 100-200 m pada Musim Barat dan Musim Timur}

Pola pada musim barat (Gambar 2) arus di Laut Jawa mengalir ke barat. Arus ini menuju ke arah tenggara yaitu Samudera Hindia keluar melalui Selat Sunda. Arus di Laut Banda cukup kuat, tidak sebanding dengan yang dapat ke luar melewati Laut Maluku, Laut Seram, dan Laut Arafuru. Akibatnya air di Laut Banda ini akan menumpuk dan akhirnya tenggelam (sinking). Di bagian utara khatulistiwa arus munuju ke arah timur laut dengan kecepatan $20 \mathrm{~cm} / \mathrm{s}$. Sedangkan pada musim timur (Gambar 2) memperlihatkan arus di Laut Jawa mengalir ke timur. Di Laut Banda arus kuat yang ke luar menuju Laut Flores dan Laut Timor hingga terjadi kekosongan yang tidak sepenuhnya dapat tergantikan oleh arus permukaan sekitarnya. Dan akibatnya, air pada lapisan bawah naik ke permukaan (upwelling) hingga membuat Laut Banda subur. Pada musin timur arus di bagian utara khatulistiwa berbalik arah menuju ke arah tenggara dengan kecepatan $40 \mathrm{~cm} / \mathrm{s}$. 


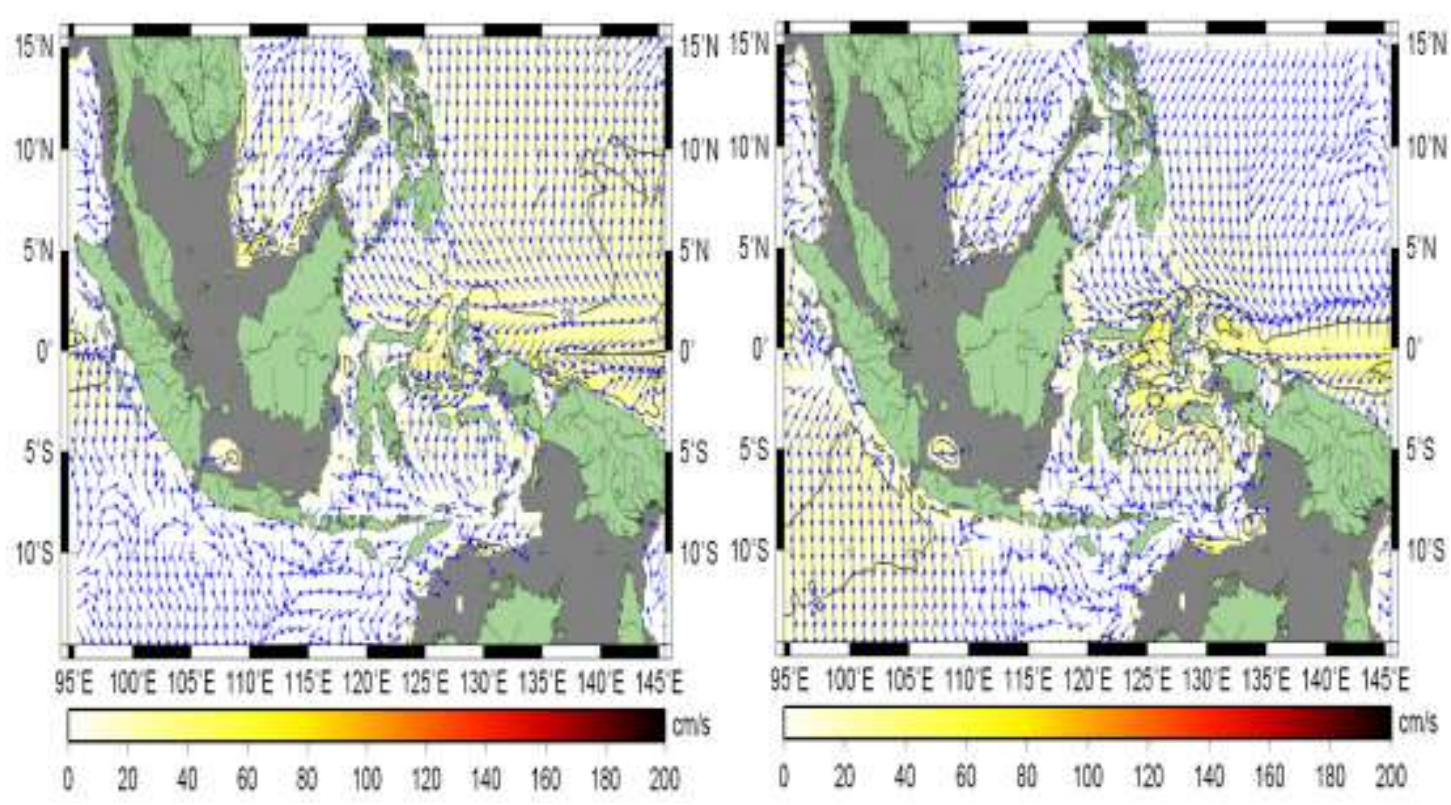

Gambar 2. Pola arus lapisan 100-200 m pada bulan Februari (Musim Barat) dan Agustus (Musim Timur).

\subsubsection{Arus Lapisan Dasar pada Musim Barat dan Musim Timur}

Pada musim barat (Gambar 3) arus yang mengalir pada bulan Februari tidak konsisten ke satu arah saja. Arus menuju ke arah barat laut, barat daya, dan timur laut, tetapi lebih dominan menuju ke timur laut. Di Selat Malaka dan Selat Sunda arus laut mengalir ke luar menuju ke Samudera Hindia. Pada Selat Karimata hingga ke Laut Flores bisa dijumpai arus dengan kecepatan sekitar $60 \mathrm{~cm} / \mathrm{s}$. Arus Laut Jawa secara umum mengalir dari barat ke timur. Laut Maluku menerima arus yang datang dari Laut Banda. Di Laut Banda, arus dari Laut Flores mengalir masuk. Sebagian arus ini kemudian mengalir ke sebelah utara Pulau Buru masuk ke Laut Seram dan dari sini melewati Laut Halmahera terus masuk ke Samudera Pasifik. Sebagian lagi arus bergerak di sebelah selatan Pulau Seram dan masuk ke Laut Arafuru.

Lapisan yang sudah tidak terpengaruh angin, pergerakan arus berjalan dengan lambat. Pada Musim Barat di Laut Banda Arus keluar pada kedalaman sekitar $1.000 \mathrm{~m}$ ke Samudera Hindia melalui Laut Timor dan merayap sampai ke Madagaskar. Dapat pula diketahui bahwa meskipun aliran arus berjalan lambat tetapi sudah cukup untuk memberi ventilasi atau pertukaran air pada palung-palung terdalam sekalipun.

Bulan Agustus pada musim timur (Gambar 3) arah arus telah di Laut Jawa berbalik sepenuhnya menuju ke barat laut yang akhirnya menuju ke Laut Cina Selatan dengan kecepatan 20-40 cm/s, tapi di sepanjang pantai utara Flores sampai Kepulauan Alor terdapat arus yang masih tetap menuju ke tenggara, barat daya, dan selatan. Sama seperti pada musim barat di Selat Malaka dan Selat Sunda arus laut mengalir ke luar menuju ke Samudera Hindia. Tomosada (1989) mendapatkan bahwa arah dari arus musim di Selat Sunda bervariasi, meskipun secara umum dapat dikatakan bahwa arahnya tetap menuju ke arah Lautan Hindia. Laut Maluku menerima arus yang datang 
dari utara Irian yang terlebih dulu melingkari ujung selatan Halmahera untuk kemudian berbelok ke utara dan kembali ke Samudera Pasifik. Di pesisir utara Irian terdapat Arus Khatulistiwa Selatan dari Samudera Pasifik yang arusnya kuat menuju ke barat.

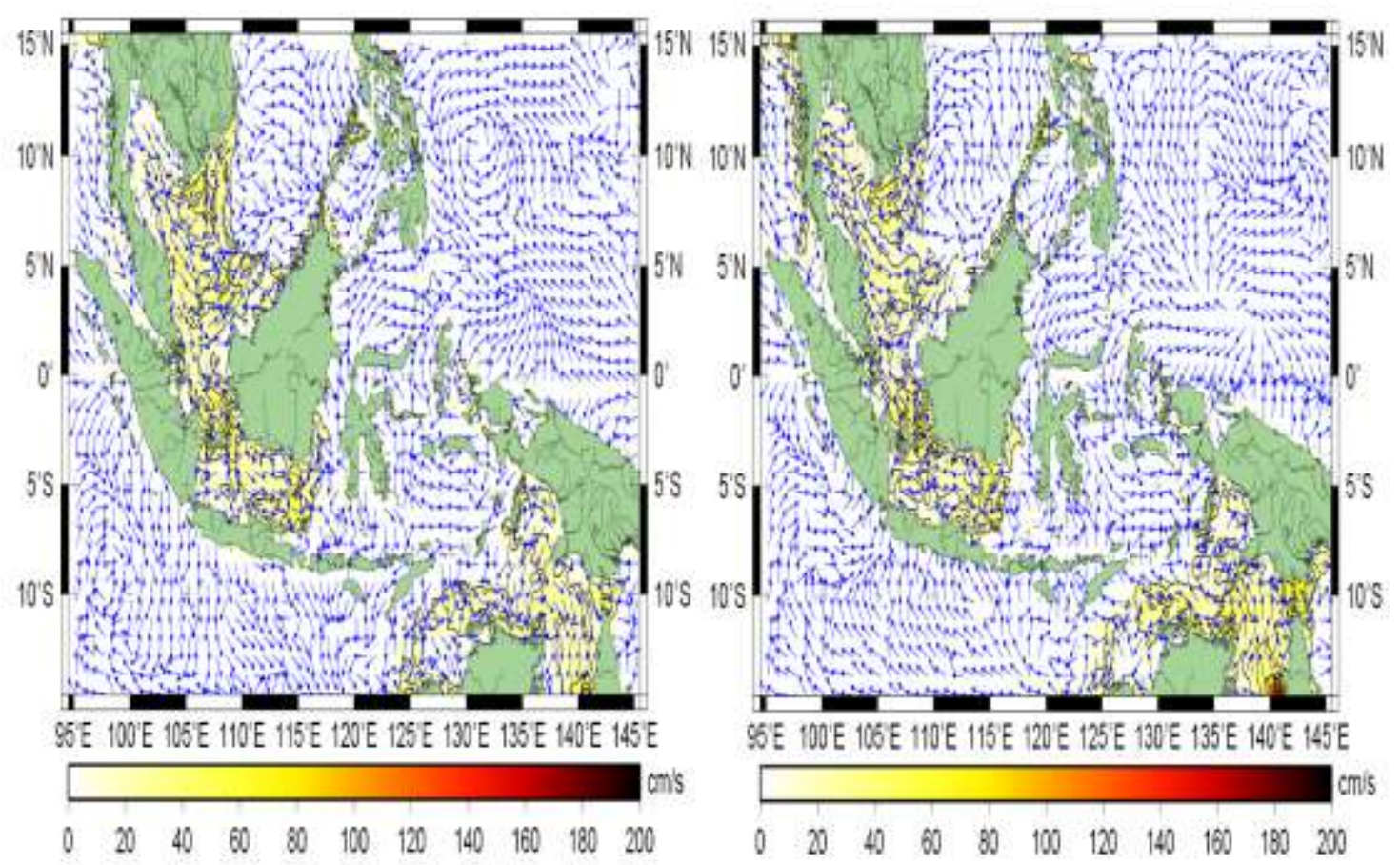

Gambar 3. Pola arus lapisan dasar pada bulan Februari (Musim Barat) dan Agustus (Musim Timur).

\subsection{Angin}

Perairan Indonesia yang berada di daerah sekitar khatulistiwa dan secara geografis terletak antara dua benua, Asia dan Australia, dan dua samudera, Hindia dan Pasifik, sangat dipengaruhi oleh angin Musim. Angin Musim di atas perairan Indonesia mengalami pembalikan arah dua kali dalam setahun. Pembagian ini lebih dikenal dengan :

1. Musim Barat (Desember - Februari)

2. Musim Timur (Juni-Agustus)

\subsubsection{Angin Musim Barat}

Selama periode ini (Gambar. 4) di daerah yang membentang dari ujung Sumatera bagian selatan, Jawa, Bali, Lombok, Nusa Tenggara sampai ke Irian angin bertiup dari barat ke timur. Sedangkan di daerah yang mencakup sebagian besar Sumatera lainnya dan Kalimantan Barat angin datang dari arah timur Laut. Hal ini sejalan dengan pola angin dalam Prawirowardoyo (1996). 


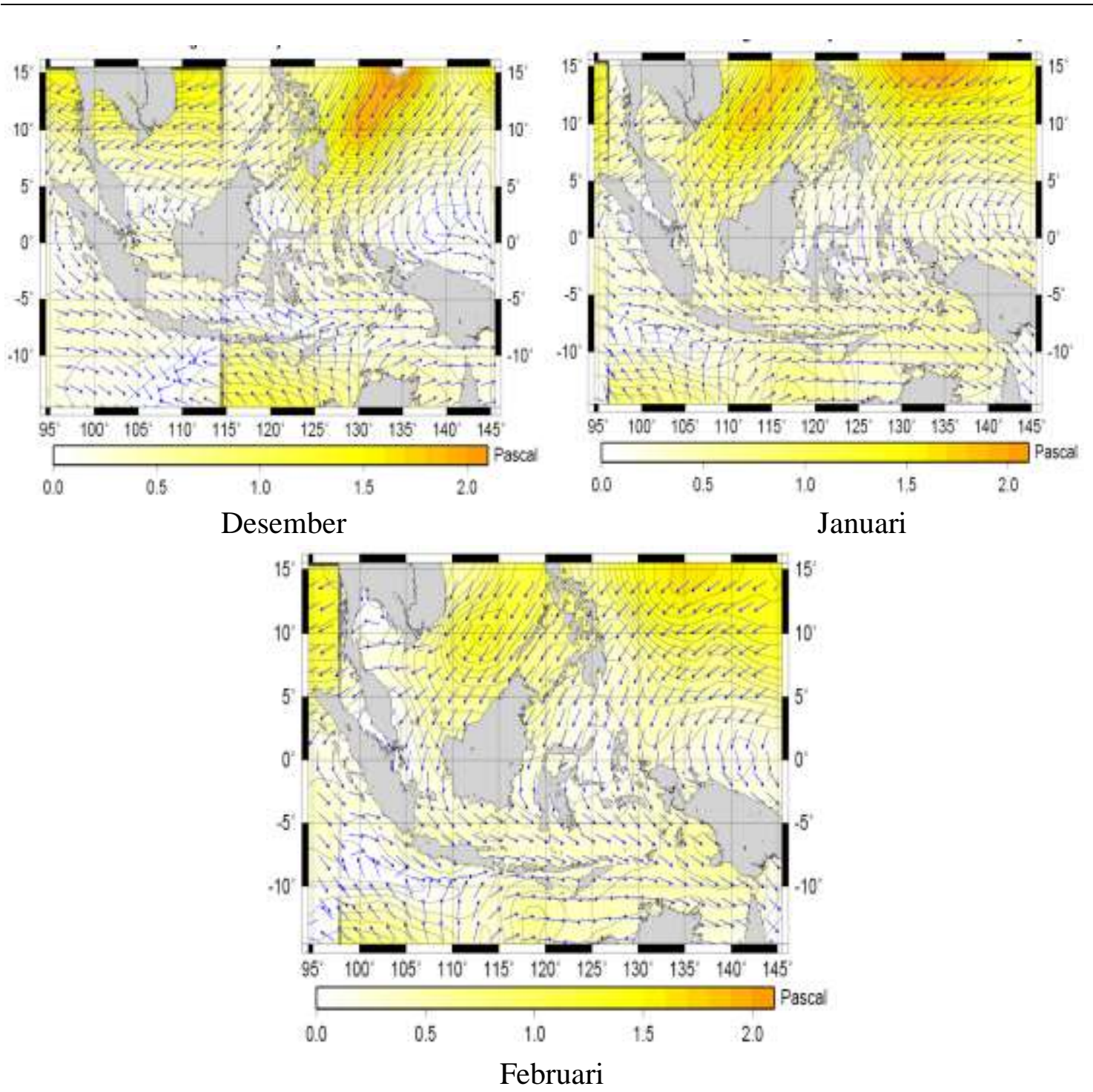

Gambar 4. Sistem angin di Perairan Indonesia pada bulan Desember-Februari

\subsubsection{Angin Musim Timur}

Di daerah yang membentang dari ujung Sumatera bagian selatan, Jawa, Bali, Lombok, Nusa Tenggara sampai Irian angin bertiup dari timur ke barat (Gambar 5). Dalam Prawirowardoyo (1996) di daerah yang mencakup Sumatera lainnya dan Kalimantan Barat angin datang dari arah barat daya ke arah timur laut. 


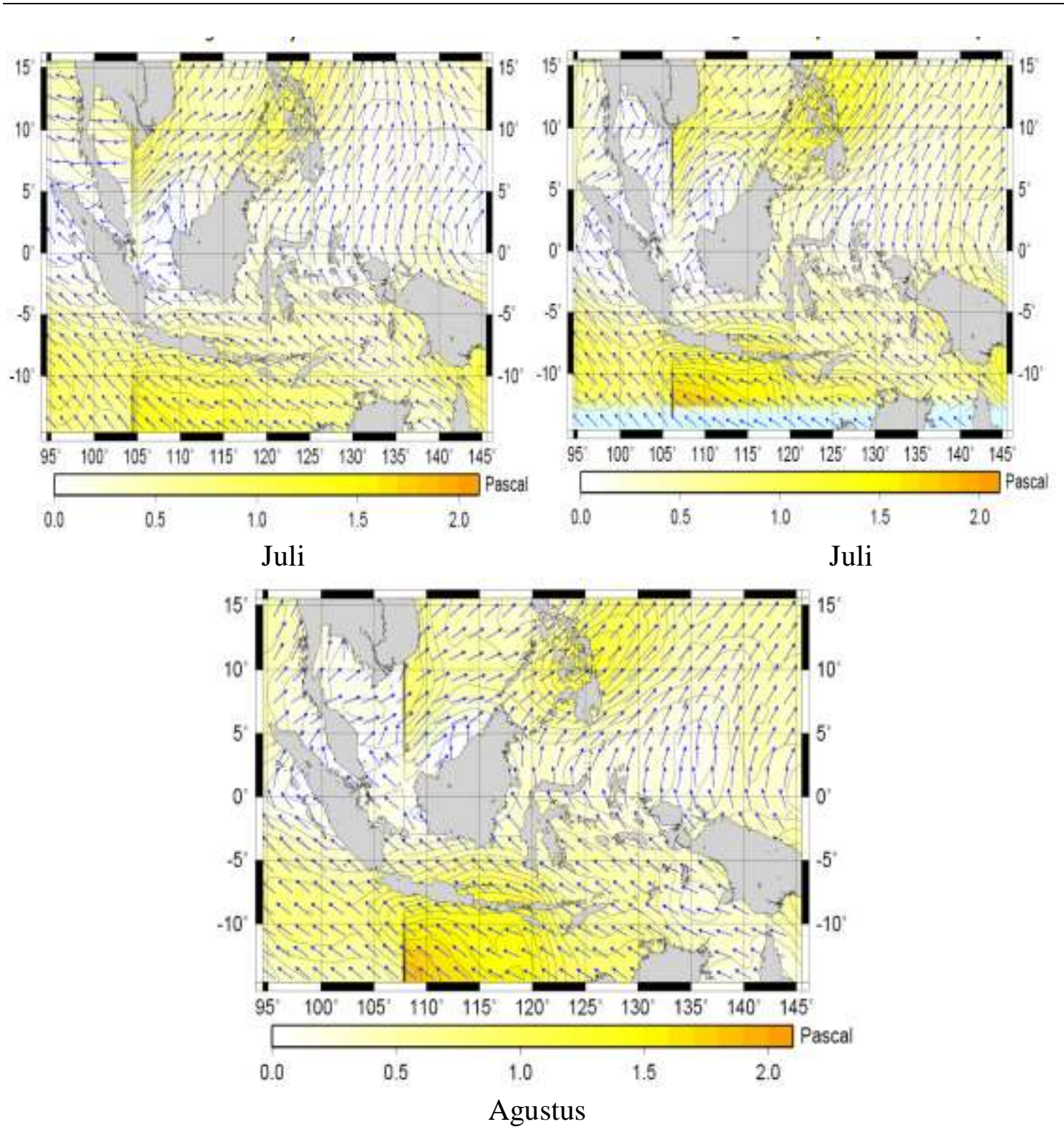

Gambar. Sistem angin di Perairan Indonesia pada bulan Juli-Agustus

\section{Kesimpulan}

1. Pola angin Hellerman pada musim barat (Desember, Januari, dan Februari) dan musim timur (Juni, Juli, dan Agustus).

2. Arus permukaan pada musim barat mengalir dari Samudera Pasifik ke arah tenggara melalui Laut Arafuru. Sedangkan pada musim timur arus yang masuk ke Samudera Pasifik mengalir ke arah timur laut dan tenggara. Arah arus pada musim timur dapat dikatakan bergerak berlawanan dengan arah angin yang bertiup dominan ke timur laut.

3. Kecepatan arus yang dominan pada lapisan 100-200 m terjadi di perairan khatulistiwa bagian timur dan sekitar Laut Cina Selatan pada musim barat di mana kecepatan arus mencapai $20 \mathrm{~cm} / \mathrm{s}$. Sedangkan pada musim timur selain terjadi di 
perairan khatulistiwa bagian timur juga terjadi di Laut Maluku, Laut Seram, dan sekitar Laut Arafuru di mana kecepatan arus mencapai $40 \mathrm{~cm} / \mathrm{s}$.

4. Kecepatan arus yang dominan pada lapisan dasar terjadi diperairan yang sama. Pada musim barat di Laut Arafuru dan Laut Timor kecepatan arus $20 \mathrm{~cm} / \mathrm{s}$. Di Laut Cina Selatan hingga ke Laut Jawa terjadi arus dengan kecepatan 20-70 cm/s. Sedangkan pada musim timur di Laut Arafuru dan Laut Timor kecepatan arus mencapai 20-60 cm/s. Di Laut Cina Selatan hingga ke Laut Jawa terjadi arus dengan kecepatan $20-40 \mathrm{~cm} / \mathrm{s}$.

5. Ketiga lapisan di atas menunjukan bahwa arus laut Indonesia lebih banyak mendapatkan air dari Samudera Pasifik. Meskipun Indonesia berbatasan langsung dengan Samudera Hindia namun ternyata samudera ini hanya mempunyai peranan kecil sekali pergerakan arus di Perairan Indonesia.

\section{Daftar Pustaka}

Arief D. 1994. Sirkulasi Arus Laut. Diktat Kursus Oseanografi bagi Perwira TNI-AL, LON-LIPI. Jakarta. hlm.11.

Djamil, S. A., 2006, Negeri Di Batas Dua Samudra Menggenggam Urat Nadi Ekonomi Dunia, http://io.ppi-jepang.org/article.php?id=126. Tanggal Download 15 Mai 2007

Dahuri R, Rais J, Ginting SP, Sitepu MJ. 1996. Pengeloaan Sumber Daya Wilayah Pesisir dan Lautan Secara Terpadu. Pradnya Paramita. Jakarta. hlm.36.

Mann KH, Lazier JRN. 1991. Dynamics of Marine Ecosystems. Blackwell Scientific Publications. Cambridge. p.164.

Nontji A. Laut Nusantara. Djambatan. Jakarta.2005. hlm.45.

Pond S, Pickard LG. 1983. Introductory Dynamical Oceanography. Second Edition. Pergamon Press. New York

Prawirowardoyo S. 1996. Mereorologi, Penerbit ITB, Bandung.

Rizal S. 2004. Modelling of Tides in the Southeast Asian Waters, Preprint submitted to Elsevier Science, Marine and Fishery Studies, Syiah Kuala University, Banda Aceh.

Stewart RH. 2002. Intoduction to Physical Oceanography. Departement Oceanography.

Texas A\&M University.

Wyrtki K. 1961. Physical Oceanography of the South East Asian Waters. Published by the Scripps Institution of Oceanography. University of California. San Diego. C.A. $195 \mathrm{pp}$.

Zahel W, Gavinko JH, Seiler U. 2000. Angular Momentum and Energy Budget of a Global Ocean Tide Model with Data Assimilation. GEOS 20. 400-413. 